\title{
Relationship between Diabetes Mellitus and Low Back Pain in the Clinics of Traditional Iranian Medicine
}

\author{
Fariba Heidari, Maryam Baradaran-Binazir* and Fatemeh Ranjbar-Oskouei \\ Social Determinants of Health Research Center, Health Management and Safety Promotion Research Institute, Tabriz University of Medical Sciences, \\ Iran
}

Submission: May 5, 2021; Published: June 02, 2021

*Corresponding author: Maryam Baradaran-Binazir, Social Determinants of Health Research Center, Health Management and Safety Promotion Research Institute, Faculty of Medicine, Tabriz University of Medical Sciences, Golgasht Ave. Tabriz, Iran

\begin{abstract}
Low back pain is commonly identified among diabetic patients, yet it is not determined if there is a causal association. The aim of this study was to identify associations between low back pain and diabetes in an Iranian population. This cross-sectional study was done on the patients with low back pain referred to traditional medicine clinics in Tabriz, East Azarbayjan, Iran, 2019. A short checklist about the presence diabetes and body mass index was applied to identify diabetic patients. Totally 210 patients participated in our study. A total of 31 women (23.6\%) and 21 men $(26.5 \%)$ reported that they had diabetes. Our study found that that the prevalence of low back pain in diabetic patients was approximately greater than non-diabetic patients.
\end{abstract}

Keywords: Diabetes; Low back pain; BMI; Musculoskeletal; Hyperglycemia

\section{Introduction}

Diabetes is a prevalent metabolic disorder that demonstrates the sign and symptoms of hyperglycemia [1]. Low back pain is the most prevalent musculoskeletal system disease and the main element of inability universally. Based on statistics approximately $80 \%$ of the people will have a period of low back pain once throughout their lives [2]. Low back pain is commonly identified among diabetic patients, yet it is not determined if there is a causal association [3]. Even though the definite pathology of diabetes associated with low back pain is ambiguous, there is evidence that atypical collagen impeachment in the musculoskeletal texture changes the anatomical and the mechanical features of these tissues [4]. The relationship between diabetes and musculoskeletal deterioration were somewhat associated with other factors in diabetic patients as defective blood circulation [3]. Furthermore, diabetes and low back pain have common risk factors like high body mass index, sedentary life and smoking [2]. In epidemiological investigations, the incidence of musculoskeletal pain has been seen to be high in diabetic patients in areas such as the shoulder, neck, back, arms, knees and hips [5]. There are very rare population-based investigations of relations between diabetes and low back pain [2]. In an investigation of Danish patients with diabetes, the prevalence of low back pain was quite greater among the diabetic patients [6]. However, in a longitudinal study of adult Spanish twins, low back pain was not reported to raise the risk of diabetes relatively [7]. The aim of the current study was to study associations between low back pain and diabetes in an Iranian population, in the clinics of traditional medicine in Tabriz. This city is the capital of East Azerbaijan Province, in northwestern Iran.

This cross-sectional study was done on the patients with low back pain referred to traditional medicine clinics in Tabriz, East Azarbayjan, Iran. The study conducted from July to December 2019. A total of 210 patients with low back pain participated in our study. We applied Krejcie and Morgan's table to calculate the sample size [8]. We asked the participants to complete a short checklist about the presence Diabetes and body mass index. Nearly $25 \%$ of participants were determined as having the diagnosis of type 2 diabetes. A total of 31 women (23.6\%) and 21 men $(26.5 \%)$ reported that they had diabetes (Table 1). These patients had a mean age of 53.1 years. A major part of patients (98.7\%) had type 2 diabetes. The mean highest recorded BMI was $35.6 \mathrm{~kg} / \mathrm{m} 2$.Data analysis was done applying chi-square test and independent t-test with a $\mathrm{P}<0.05$ by SPSS software (version 16). This study was approved by the Ethics Committee of Tabriz University of Medical Sciences with an ethical approval number of IR.TBZMED.REC.1397.947. 


\section{Current Research in Diabetes \& Obesity Journal}

Table 1: Association of diabetes and low back pain with BMI, sex and smoking among 210 patients, using Chi-square test and independent t-test.

\begin{tabular}{|c|c|c|c|}
\hline Variables & Low Back Pain No Diabetes & Low Back Pain and Diabetes & P \\
\hline Mean BMI $\left(\mathrm{kg} / \mathrm{m}^{2}\right)^{*}$ & 30.51 & 34.12 & $<0.001$ \\
\hline Female sex(N) & 100 & 31 & $<0.001$ \\
\hline Smoking(N) & 31 & 29 & 0.12 \\
\hline
\end{tabular}

\section{Conclusion}

The present study found that the prevalence of low back pain in diabetic patients was approximately greater than non-diabetic patients. The association is not related to gender. The association is found among women and men. In smokers, no relationship can be established.

\section{Acknowledgements}

We appreciate all patients participated in this study.

\section{References}

1. L Guariguata, D R Whiting, I Hambleton, J Beagley, U Linnenkamp, et al. (2014) Global estimates of diabetes prevalence for 2013 and projections for 2035. Diabetes Res Clin Pract 103(2): 137-149.

2. Ingrid Heuch, Ivar Heuch, Knut Hagen, Elin Pettersen Sørgjerd, Bjørn Olav Åsvold, et al. (2018) Is chronic low back pain a risk factor for diabetes? The Nord-Trøndelag Health Study. BMJ Open Diabetes Res Care 6(1): e000569.
3. Eivazi M, Abadi L (2012) Low back pain in diabetes mellitus and importance of preventive approach. Health promotion perspectives 2(1): 80.

4. Arkkila PE, Gautier JF (2003) Musculoskeletal disorders in diabetes mellitus: an update. Best pract Research Clin Rheumatol 17(6): 945970.

5. M Heliövaara, M Mäkelä, P Knekt, O Impivaara, A Aromaa (1991) Determinants of sciatica and low-back pain. Spine 16(6): 608-614.

6. Molsted S, Tribler J, Snorgaard O (2012) Musculoskeletal pain in patients with type 2 diabetes. Diabetes Res Clin Pract 96(2): 135-140.

7. Dario A, Ferreira M, Refshauge K, Harmer A, Sánchez-Romera J, et al. (2017) Mapping the association between back pain and type 2 diabetes: a cross-sectional and longitudinal study of adult Spanish twins. PloS one 12(4): e0174757.

8. Keikavoosi-Arani L, Someah MS (2021) Assessing Levels of Occupational Stress among Clinical Dental Students. Journal of Health and safety at Work. 10(4): 23-25.

\begin{tabular}{l} 
Your next submission with Juniper Publishers \\
will reach you the below assets \\
- Quality Editorial service \\
- Swift Peer Review \\
- Reprints availability \\
- E-prints Service \\
- Manuscript Podcast for convenient understanding \\
- Global attainment for your research \\
- Manuscript accessibility in different formats \\
( Pdf, E-pub, Full Text, Audio) \\
- Unceasing customer service \\
Track the below URL for one-step submission \\
https://juniperpublishers.com/online-submission.php \\
\hline
\end{tabular}

